\title{
Recent Development of Islamic Banking Performance Measurement
}

\author{
Azis Budi Setiawan ${ }^{1 *}$, Amilin², M. Nur Rianto Al Arif ${ }^{3}$ \\ ${ }^{*}$ Corresponding author
}

\begin{abstract}
This study aims to review the development of research related to Islamic banks' performance measurement and various alternative models. It uses a meta-analysis approach to identify other previous studies from various journals and relevant researches. The results show that the measurement of Islamic bank performance mostly uses financial performance measurements similar to conventional bank performance measurements, which use financial ratios and efficiency. There have been several serious efforts to develop alternative models for measuring Islamic banks' performance to reflect their nature and objectives better. These models include the Islamicity Index, Economic Contribution and Muslim Communities, Social Performance Index, Maqashid Index, and Islamic Bank Maqashid Index. However, eventually, these models are still in the early stages of development and have several weaknesses. Thus, it is still necessary to develop a model for measuring Islamic bank performance relevant to its philosophy and objectives.
\end{abstract}

Keywords: performance measurement, organization performance, Islamic banking

JEL Classification: G21, L25

\begin{abstract}
Abstrak. Penelitian ini bertujuan untuk meninjau perkembangan penelitian terkait pengukuran kinerja bank syariah dan berbagai model alternatifnya. Penelitian ini menggunakan pendekatan meta-analisis untuk mengidentifikasi berbagai penelitian sebelumnya dari berbagai jurnal dan penelitian yang relevan. Hasil tinjauan menunjukkan bahwa pengukuran kinerja bank syariah masih dominan menggunakan pengukuran kinerja keuangan yang mirip dengan pengukuran kinerja bank konvensional, menggunakan rasiorasio keuangan dan efisiensi. Terdapat sejumlah upaya serius pengembangan alternatif model pengukuran kinerja bank syariah agar lebih mencerminkan hakikat (nature) dan tujuannya. Model-model tersebut antara lain: Islamicity Index, Kontribusi Ekonomi dan Komunitas Muslim, Indeks Kinerja Sosial, Maqashid Index, dan Indeks Maqashid Bank Syariah (IMBS). Namun dalam perkembangannya model-model tersebut masih dalam tahap awal pengembangan dan memiliki sejumlah kelemahan. Sehingga dengan demikian, masih diperlukan pengembangan model pengukuran kinerja bank syariah yang relevan dengan filosofi dan tujuannya.
\end{abstract}

Kata Kunci: pengukuran kinerja, kinerja organisasi, perbankan syariah

\section{How to Cite:}

Setiawan, A. B., Amilin., \& Al Arif, M. N. R. (2020). Recent Development of Islamic Banking Performance Measurement. Etikonomi: Jurnal Ekonomi, 19(2), 203 - 220. https://doi.org/10.15408/etk.v19i2.15706. 


\section{Introduction}

Islamic banking has developed globally and is proliferating over the past three decades, despite economic and political uncertainties in many regions throughout the world. Islamic banking has declared more resilient than conventional banking on the effects of the global financial crisis shocks (Kasim \& Majid, 2010; Hasan \& Dridi, 2010, 2011; Khediri et al., 2015; Hussein et al., 2019). Furthermore, Islamic banking can control costs well, so it is considered more efficient than conventional banking (Rahim et al., 2013; Saeed \& Izzeldin, 2016; Safiullah \& Shamsuddin, 2018). Islamic banking offers its customers several attractive features in products and services in experiencing an expeditious growth. However, some argue that Islamic banking has failed to deliver tangible social results, so it needs to improve its performance (Asutay, 2007; Sairally, 2007; Asutay, 2012; Mohd Nor, 2016; Mohd Nor et al., 2016; Hamidi \& Worthington, 2018).

In the development of Islamic banking, there are no standard measurement tools to evaluate Islamic banking's appropriate and relevant performance (Ascarya et al., 2017). In general, the Islamic banking performance measurement model is still a new academic discourse even though the theme related to Islamic banking performance has become a broad discussion. Also, in-depth research related to the theoretical basis, concepts, and methods of measuring Islamic bank performance is still limited.

Research on Islamic bank performance measurement models is also related to research in strategic management that can classify in two interrelated flow: substantive and measurement (Schwab, 1980; Venkatraman \& Grant, 1986; Carton, 2004; Carton \& Hofer, 2006). Substantive flow is related to studies that focus on theoretical relationships between independent and dependent variables. The measurement flow is related to the validity of the operationalization of concepts and constructs, both the measurement of independent and dependent variables. According to Carton and Hofer (2006), the flow of measurement research in its development has received little attention so far, mostly related to the measurement of the dependent variable.

As the concept of performance is contextual, the condition of an organization uses to represent performance. In its development, most management research focuses on performance determinants. Research related to measurement is still limited, even though it is a fundamental and essential factor (Carton, 2004; Carton \& Hofer, 2006; Logofatu \& Stefanescu, 2017; Stefanescu \& Logofatu, 2018). The performance measurement methods of Islamic banking also still lacked in-depth discussion and research. The accurate and comprehensive performance measurement for Islamic banking is crucial in developing effective and sustainable Islamic banking.

Lucianetti et al. (2019) provide empirical evidence regarding the relationship between the completeness of performance measurement systems and organizational effectiveness. Neely et al. (2015) also show that acceptable performance measurement practices can significantly contribute to organizational robustness and sustainability if applied carefully and creatively. Severgnini et al. (2018) also emphasize that the performance measurement system has increased the organization's extraordinary dexterity and ambidexterity and, consequently, affects organizational performance. 
This study provides at least three contributions to the development of research related to Islamic banks. First, mapping the development of researches in the measurement of Islamic banking performance that has widespread use and various efforts to develop new methods from the early period of the establishment of Islamic banks up to the present time. Second, this research fills the research gap regarding the measurement model of Islamic banking performance, which is still limited and is still a new academic discourse. Third, this research is fundamental to see the possible direction of further development so that Islamic banking has a standardized performance measurement model that can evaluate how appropriate and relevant Islamic banking's performance is to its nature and objectives.

\section{Methods}

With relevance to the research objectives, this study uses a meta-analysis approach to identify relevant research in various journals and relevant research based on developing research topics (Fetscherin \& Heinrich, 2015; Alon et al., 2018). This study also refers to bibliographic research as part of the meta-analysis approach, as carried out by Dewi et al. (2018) and Setyaningsih \& Setiawan (2019), although it is more limited in research substance.

Due to the limited number of research in this area, the publication criteria from previous studies include all journals and research accessible and following this theme. This research uses a thematic approach that follows to gather most research published in the last 30 years that discusses the theory, development, and use of various alternative models of Islamic bank performance measurement. This study has followed three main themes: Islamic bank performance, model development of Islamic bank performance measurement, and various existing performance measurement models.

\section{Result and Discussion}

In general, Islamic banks' performance measurement still mostly uses performance measurements that are similar to conventional bank performance measurements that use financial ratios and efficiency (technical and cost). Various methods mostly measure Islamic banking performance with approaches to measuring efficiency and financial performance, which tend to be the same as conventional bank performance measurement. The measurement of Islamic banking efficiency commonly used is Data Envelopment Analysis (DEA) method. The majority of research in this realm compares the efficiency between Islamic banking and conventional banking to see which one is more efficient. Then, some studies combine DEA with the Malmquist Productivity Index to measure Islamic banking productivity (Ahmad \& Rahim, 2012; Alkheil et al., 2013; Johnes et al., 2014; Mobarek \& Kalonov, 2014; Sillah \& Harrathi, 2015; Masum et al., 2016; Abbas et al., 2016; Kamarudin et al., 2017; Hafez, 2018). Other efficiency studies use the stochastic frontier model, meta-frontier approach, and meta-frontier Malmquist productivity index (MPI) (Abid et al., 2018; Johnes et al., 2018).

Financial performance measurement approaches are also commonly used to measure the performance of Islamic banking from various countries (Usman \& Khan, 2012; El- 
Mosaid \& Boutti, 2012; Alkheil et al., 2013; Wasiuzzaman \& Gunasegavan, 2013; Eljelly \& Elobeed, 2013; Hadriche, 2015; Noman et al., 2015; Khediri et al., 2015; Zaheer \& Jamil, 2016; Rashid \& Jabeen, 2016; Khan et al., 2017; Airout \& Airout, 2017; Doumpos et al., 2017). Financial ratios from the CAMEL framework (capital, assets quality, management, earnings, and liquidity) often use to measure Islamic banking performance. Both only the CAMEL ratio use to measure Islamic bank performance or combined with macroeconomic variables such as inflation, GDP, interest rates, and unemployment rates (Kouser \& Saba, 2012; Erol et al., 2014; Ifeacho \& Ngalawa, 2014; Hadriche, 2015; Rashid \& Jabeen, 2016; Suresh \& Bardastani, 2016). Likewise, researches in Islamic banking performance in Indonesia use many approaches to measuring financial performance (Mahfudz, 2006; Rosyadi, 2007; Arsil, 2007; Prawira, 2007; Siswantoro 2014; Abusharbeh, 2016; Sukmana \& Febriyati, 2016; Setyawati et al., 2017; Hamid et al., 2017; Saiful \& Ayu, 2019).

In addition to the financial approach, some studies seek to formulate alternative models for measuring Islamic banks' performance that is more in line with their nature and objectives. Efforts to formulate an alternative measurement model because Islamic bank performance with the financial approach sees as not paying attention to broader stakeholder goals and macroeconomic goals (Ascarya et al., 2017). Moreover, measuring Islamic banking performance with the use of financial performance measurements using conventional bank performance measurement models is seen as incompatible with the philosophy and character of Islamic banks.

According to Hameed et al. (2004), performance evaluation root in the Muhasabah concept highly recommends for both individual and corporate scale from an Islamic perspective. The Muhasabah concept can be an essential philosophical foundation for representation of performance evaluation in modern Islamic organizations or institutions, including Islamic banking. They also stressed that financial performance measurement tools such as ROI (return on investment) derived from the paradigm of Western civilization thinking, including those used for conventional banking, are not entirely appropriate because it bases on a positivist utilitarian paradigm. It then leads the researchers to formulate alternative performance measures for Islamic banks. There are strong aspirations from researchers and thinkers to develop alternative models of Islamic bank performance measurement to reflect nature and its objectives better.

From the results of this study, from the early period of Islamic banking development to the present time, the development of alternative models for measuring Islamic banks' performance is limited and still early. Some alternative models of measuring the performance of Islamic banks that develop can group as follows. First, Islamicity Index, Economic Contribution and Muslim Community, and Social Performance Index (Samad \& Hasan, 2000; Hameed et al., 2004; Setiawan, 2009; Aisjah \& Hadianto, 2013; Zainal \& Putra, 2016; Mukhibad et al., 2017; Wiranata \& Rama, 2018; Sabirin, 2018; Mutia et al., 2019); Second, Maqashid Index and Islamic Bank Maqashid Index (Mohamed et al., 2008; Mohamed \& Taib, 2009, 2015; Antonio et al., 2012; Hartono \& Sobari, 2017; Asutay \& Harningtyas, 2015; Ascarya et al., 2016; Qasim et al., 2017; Ascarya et al., 2017). 
Table 1. Some of the Islamicity Index and Social Performance Research

\begin{tabular}{|c|c|c|c|}
\hline Researcher & Objectives & Dimension and Variables & Results \\
\hline $\begin{array}{l}\text { Samad \& Hasan } \\
(2000)\end{array}$ & $\begin{array}{l}\text { Comparative } \\
\text { performance of } \\
\text { Islamic banks and } \\
\text { conventional banks }\end{array}$ & $\begin{array}{l}\text { Financial performance: ratio profitability, } \\
\text { liquidity, risk and solvency. } \\
\text { Economic Development Commitment: } \\
\text { (1) Long term loan ratio (LTA): long } \\
\text { term loan/total loans; (2) Government } \\
\text { Bond Investment ratio (GBD): Deposit } \\
\text { invested in government bond/Total } \\
\text { Deposit; (3) Mudaraba-Musharaka Ratio } \\
\text { (MM/L): Mudaraba-Musharaka/Total } \\
\text { Loans. }\end{array}$ & $\begin{array}{l}\text { The contribution to development } \\
\text { is no better compared to } \\
\text { conventional bank groups, } \\
\text { although the F-value is not } \\
\text { significant. }\end{array}$ \\
\hline $\begin{array}{l}\text { Hameed et al. } \\
\text { (2004) }\end{array}$ & $\begin{array}{l}\text { Formulating } \\
\text { Islamicity Disclosure } \\
\text { Index and Islamicity } \\
\text { Index. }\end{array}$ & $\begin{array}{l}\text { Islamicity Index with variables: Profit- } \\
\text { sharing ratio; Zakat performance ratio; } \\
\text { Equitable distribution ratio; Directors- } \\
\text { Employees welfare ratio; Islamic } \\
\text { Investment vs Non-Islamic Investment } \\
\text { ratio; dan Islamic Income vs Non-Islamic } \\
\text { Income ratio. }\end{array}$ & $\begin{array}{l}\text { Bahrain Islamic Bank (BIB) } \\
\text { generally has better social } \\
\text { performance than the Islamic } \\
\text { Bank of Malaysia Berhad (BIMB). }\end{array}$ \\
\hline Setiawan (2009) & $\begin{array}{l}\text { Continuing } \\
\text { to develop } \\
\text { measurement of } \\
\text { social performance } \\
\text { in Islamic banks. }\end{array}$ & $\begin{array}{l}\text { Financial Performance: Asset Quality, } \\
\text { Rentability, and Liquidity } \\
\text { Social Performance: Ratio of } \\
\text { Contributions to Economic } \\
\text { Development, Contributions to } \\
\text { the Community, Contributions to } \\
\text { Stakeholders, Increased SDI and } \\
\text { Research, and Distribution of Economic } \\
\text { Development. }\end{array}$ & $\begin{array}{l}\text { During the period of } 2003-2007 \text {, } \\
\text { BSM's social performance was } \\
\text { better than BMI. While BMI's } \\
\text { financial performance is better } \\
\text { than BSM in the same period. }\end{array}$ \\
\hline $\begin{array}{l}\text { Aisjah \& Hadianto } \\
\text { (2013) }\end{array}$ & $\begin{array}{l}\text { Evaluating the } \\
\text { performance of } \\
\text { Islamic banks in } \\
\text { Indonesia during } \\
2009-2010\end{array}$ & $\begin{array}{l}\text { Islamicity Index (Hameed et al., 2004) } \\
\text { with variables: Profit-sharing ratio; Zakat } \\
\text { performance ratio; Equitable distribution } \\
\text { ratio; Directors-Employees welfare } \\
\text { ratio; Islamic Investment vs Non-Islamic } \\
\text { Investment ratio; and Islamic Income vs } \\
\text { Non-Islamic Income ratio. }\end{array}$ & $\begin{array}{l}\text { The performance of Islamic banks } \\
\text { in Indonesia gets a satisfactory } \\
\text { level of assessment. However, } \\
\text { there are two unsatisfactory } \\
\text { ratios: the zakat performance } \\
\text { ratio and the director-employee } \\
\text { welfare difference ratio. }\end{array}$ \\
\hline Sabirin (2018) & $\begin{array}{l}\text { Evaluating the } \\
\text { performance of } \\
\text { Islamic banks in } \\
\text { Indonesia during } \\
\text { 2013-2017 }\end{array}$ & $\begin{array}{l}\text { Islamicity Index (Hameed et al., 2004) } \\
\text { with variables: Profit-sharing ratio; } \\
\text { Zakat performance ratio; Equitable } \\
\text { distribution ratio; Directors-Employees } \\
\text { welfare ratio; Islamic Investment vs } \\
\text { Non-Islamic Investment ratio; dan } \\
\text { Islamic Income vs Non-Islamic Income } \\
\text { ratio. }\end{array}$ & $\begin{array}{l}\text { The performance of Islamic } \\
\text { banking in Indonesia is quite } \\
\text { good. However, there are two } \\
\text { unsatisfactory ratios, namely the } \\
\text { zakat performance ratio and the } \\
\text { director-employee welfare ratio. } \\
\text { This study shows that zakat paid } \\
\text { by Islamic banks in Indonesia is } \\
\text { still low and there is still a large } \\
\text { gap between the welfare of } \\
\text { directors and employees. }\end{array}$ \\
\hline Mutia et al. (2019) & $\begin{array}{l}\text { Evaluating the } \\
\text { performance of } \\
\text { Islamic banks in } \\
\text { Indonesia }\end{array}$ & $\begin{array}{l}\text { Five ratios are used in Islamicity } \\
\text { Performance Index: profit sharing, } \\
\text { charity, equitable distribution, the } \\
\text { welfare of directors and employees and } \\
\text { incomes, Islamic vs. non-Islamic income } \\
\text { source. }\end{array}$ & $\begin{array}{l}\text { Bank of Muamalat Indonesia well } \\
\text { applied the best performance } \\
\text { of profit sharing ratio, charity } \\
\text { welfare of directors and } \\
\text { employees. Bank of Sharia } \\
\text { Mandiri had the highest place } \\
\text { in the implementation of the } \\
\text { Equitable Distribution Ratio. } \\
\text { Bank of BRI Sharia had the } \\
\text { highest position in determining } \\
\text { the Islamic Incomes vs. Non- } \\
\text { Islamic Incomes ratio. The } \\
\text { conclusion for overall is the } \\
\text { Islamic Banks have applied the } \\
\text { Islamicity Performance Index in } \\
\text { performance measurement. }\end{array}$ \\
\hline
\end{tabular}


The earliest attempt to develop alternative performance measures for Islamic banks was made by Samad \& Hasan (2000) two decades ago. This effort is based on an awareness that Islamic banks' performance is sufficiently measured by financial performance and its contribution to the economy and its alignments with the Muslim community. To evaluate the economic contribution and its partiality of Islamic banks toward the Muslim community, Samad \& Hasan (2000) use several variables as follows: (1) Long term loan ratio (LTA): long term loan/total loans; (2) Government Bond Investment ratio (GBD): Deposit invested in government bonds/Total Deposit; (3) Mudaraba-Musharaka Ratio (MMR): Mudaraba-Musharaka/Total Loans.

The next serious attempt to formulate alternative performance measurement methods unique to Islamic banks is carried out by Hameed et al. (2004). In addition to formulating the Islamicity Disclosure Index, an Islamicity Index was also formulated. This effort can call as the first attempt to develop alternative performance measurement tools for Islamic banks in an index with a separate name. In the Islamicity Index, Hameed et al. (2004) included six main performance variables: Profit-sharing ratio, Zakat performance ratio; Equitable distribution ratio, Directors-Employees welfare ratio; Islamic Investment vs. Non-Islamic Investment ratio; and Islamic Income vs. Non-Islamic Income ratio. This research has become an essential initial foundation to see the possibility of developing alternative models for measuring Islamic banks' performance by bringing up new performance variables that are considered following the nature and unique character of Islamic banks. Efforts to develop dimensions, elements, and proxies for Islamic bank social performance were then continued by Setiawan (2009) by synthesizing the Samad \& Hasan (2000) approach, Hameed et al., (2004), as well as proxies for Islamic bank health assessment from Bank Indonesia (2007) which has a social dimension.

In general, there are quite a lot of subsequent studies that try to evaluate the performance of Islamic banks using the Islamicity Index method and measurement of social performance that has developed both overall and by taking some of its variables (Aisjah \& Hadianto, 2013; Laela, 2014; Zainal \& Putra, 2016; Mukhibad et al., 2017; Wiranata \& Rama, 2018; Sabirin, 2018; Mutia et al., 2019). Unfortunately, these studies only use these methods without further development related to developing dimensions, variables, and their proxies (see Table 1).

Next, research on the development of alternative models for measuring Islamic banks' performance that is increasingly conducted is performance measurement based on Maqashid Sharia or Maqashid Index. The models vary from simple to complex ones. In general, Maqashid Index becomes quite popular as the term is commonly used in academic researches. Nevertheless, there is little methodological discussion and the possibility of its use in practice. This study identifies at least three (3) developments in the Maqashid Index model that will discuss further. (Details see Table 2). 
Table 2. Variants of the Maqashid Index Model

\begin{tabular}{lll}
\hline \multicolumn{1}{c}{ Models } & Number of Dimensions and Variables & \multicolumn{1}{c}{ Researchers } \\
\hline $\begin{array}{l}\text { Three Objective Maqashid } \\
\text { Index }\end{array}$ & 3 dimensions and 10 variables & $\begin{array}{l}\text { Mohammed et al. (2008); } \\
\text { Mohammed \& Taib (2009 \& 2015) } \\
\end{array}$ \\
& 3 dimensions and 9 variables & Qasim et al. (2017) \\
\hline $\begin{array}{l}\text { Eight Objective Maqashid } \\
\text { Index }\end{array}$ & 8 dimensions dan 38 variables & Asutay \& Harningtyas (2015) \\
\hline $\begin{array}{l}\text { Five objective Maqashid } \\
\text { Index }\end{array}$ & 5 dimensions dan 18 variables & Ascarya et al. (2016) \\
\hline
\end{tabular}

First, the Maqashid Index that using three Objectives. Mohammed et al. (2008) initiated the earliest attempt to formulate the Maqashid Index to measure Islamic banks' performance. The research's main objective is to identify the ideal objectives of Islamic banking from the theory of Maqasid al-Shari'ah by exploring relevant Sharia literature and sources. They elaborated on Abu Zaharah's concept of Maqashid Sharia and found three final goals that must be achieved by Islamic banks: (1) Tahdhib al-Fard or Individual Education; (2) Iqamah al-'Adl or Enforcement of Justice; and (3) Jalb al-Maslahah or Public Benefit. The second objective of their research proposes that besides financial (commercial) measures, Islamic bank performance measures the three identified objectives. It clearly shows that from the very beginning, the Maqashid Index was designed by negating financial (commercial) measures and being a complementary performance measure. Therefore, the initial model is generally dichotomous, separating financial performance from maqashid performance.

In formulating the Index, Mohammed et al. (2008) used Sekaran's Method to operationalize Islamic banking's objectives into measurable dimensions. Deriving the concept's dimensions, which were then formulated into elements that made it possible to be observed and measured to form an index of concept measurement, developed it. Data used for this Index derive from financial statements and corporate governance reports. The model continues its development in the following Mohammed \& Taib's publications $(2009,2015)$. The Maqashid Index model developed by Mohammed and Taib is widely used by subsequent researchers, including Antonio et al. (2012); Hartono \& Sobari (2017); Qasim et al. (2017); Rusydiana \& Sanrego (2018); and Hosen et al., (2019). Qasim et al. (2017) developed a slightly different Maqashid Index by subtracting one element from the previous Index.

Secondly, the Maqashid Index using eight goals. Asutay \& Harningtyas (2015) developed the Maqashid Index, referring to the thoughts of Al-Najjar with the classification of eight (8) pillars of Islamic Maqahid to measure the performance of Islamic banks in several countries. For industrial performance, there are eight most critical Maqashid indicators according to the Al-Najjar perspective, namely safeguarding the lives, faith, and rights of stakeholders, followed by safeguarding assets, social, intellectual, and hereditary entities, and finally, the goal of ecological preservation.

In building its Index, Asutay \& Harningtyas (2015) combined weighting based on the Islamicity Disclosure Index, Ethical Identity Index, and CAMEL ratio while transforming 
the Maqashid Sharia elements into performance ratios. This model produces a fairly complex performance index, both academically but challenging to use for broader practice. For example, for the final objective component, safeguarding the physical environment, which includes the aspects of wealth and ecology, reduces quite some dimensions and elements that must be assessed quantitatively and qualitatively.

Asutay \& Harningtyas (2015) also use visual graphics with geometric and mathematical approaches. The Hexagon Method (Bedoui \& Mansour, 2015) used them in measuring the performance of Maqashid Sharia. They also formulated the Maqashid Sharia General Performance (GP) by using a balanced-orientation Maqashid performance measure formed from the sum of the eight alignments with each maximum objective value equals eight (8). According to this study, the achievement of Islamic bank performance is not satisfactory due to the lack of achievement of social goals and environmental preservation. Bank of Sharia Mandiri (BSM) obtained the highest value with a score of 59.41 percent from 282.84 percent, and the lowest, the European Islamic Investment Bank (EIIB) obtained 7.01 percent. Meanwhile, for the country's performance, the highest score was obtained by Indonesia ( 56.83 percent), followed by Pakistan, Malaysia, Turkey, Qatar, and the United Kingdom. In further developments, unfortunately, researchers in subsequent studies have not used the Maqashid Index Asutay \& Harningtyas's (2015) model as it is very complex and impractical to use.

Third, Maqashid Index that using five objectives. The next attempt to develop the Maqashid Index with a new name is the Islamic Bank Maqashid Index, which was carried out by Ascarya et al. (2016) by developing the concept of Al-Ghazali’s Maqashid Sharia with five main objectives. The concept of Al-Ghazali's Maqashid Sharia initially elaborated by Chapra (2008), who made it details on each of the five objectives to reach 42 elements. Then it was modified by Bedoui \& Mansour (2015), which gave weight to each of the 42 elements. By combining weighting and transforming these elements into performance ratios, they use visual graphics (pentagon) through a combination of geometric and mathematical approaches. They then visualize all the Maqashid Sharia performance into a spider chart form.

Ascarya et al. (2016) then elaborated on the weighting carried out by Bedoui and Mansour (2015) by using the Analytical Network Process (ANP) and regrouping the categories of each Chapra element (2008). The difference is in the weighting conducted by Bedoui \& Mansour based only on descriptive analysis and literature review, but Ascarya et al. (2016) weighted using the Analytical Network Process (ANP). Their research then limited the dimensions of the Index to four dimensions for each of the five objectives, citing observable data availability. Then, from the weighted results of the Maqashid Sharia dimensions selected above, they interpreted the Maqashid Sharia elements' proxy with the Sekaran's Concepts of Operationalization Method (SCOM).

Until now, no ones researchers have used the Islamic Bank Maqashid Index model in subsequent studies in its development. This condition is likely because researchers prefer to use the simpler Mohammed \& Taib Maqashid Index Model. Ascarya et al. (2017) then continued their research related to the Islamic Bank Maqashid Index that was different from the Islamic Bank Maqashid Index design in a previous study that derived elements 
from Maqashid Sharia. The research develops a new concept based not only on the AlGhazali's Maqashid Sharia with 5 (five) objectives but also interconnected with socioeconomic objectives with 3 (three) objectives. These three objectives relate to the objectives of establishing an Islamic bank economically and the law.

According to Ascarya et al. (2017), it is an effective way to implement the dimensions proposed by Chapra (2008), where these dimensions do not have to be mutually exclusive to represent just one of the objectives of Sharia. However, because Chapra's dimensions aim at general economic development, modifications need to make to be applied in Islamic banks. There are conditions where the elements affect more than one goal.

In the study of Ascarya et al. (2017), sub-aspects of the sub-aspects' goals and dimensions using the Delphi Method are carries out by involving experts and scholars. From the Delphi method, the results of socio-economic objectives include (1) Commercial; (2) Social; and, (3) Macro. Each goal has 4 (four) or 5 (five) factors or sub-aspects, and each sub-aspect has 5 (five) elements. Commercial goals have 5 (five) sub-aspects and 25 elements, Social goals have 4 (four) sub-aspects and 20 elements, and Macro goals have 4 (four) sub-aspects and 20 elements. Weighting objectives, sub-aspects, and elements are then carried out using ANP, so the Islamic Bank Maqashid Index calculation is carried out in two stages using the ANP Two-level Additive Weighting (ATAW) method.

Table 3. Identification of Weaknesses in Islamic Bank Performance Measurement Models

\begin{tabular}{|c|c|c|}
\hline Measurement Model & Researcher & Weakness \\
\hline $\begin{array}{l}\text { Measurement of } \\
\text { Financial Performance }\end{array}$ & $\begin{array}{l}\text { Usman \& Khan (2012); El-Mosaid \& Boutti (2012); } \\
\text { Alkheil et al. (2013); Wasiuzzaman \& Gunasegavan } \\
\text { (2013); Eljelly \& Elobeed (2013); Hadriche (2015); } \\
\text { Noman et al. (2015); Khediri et al. (2015); Zaheer } \\
\text { \& Jamil (2016); Rashid \& Jabeen (2016); Khan et } \\
\text { al. (2017); Airout \& Airout (2017); Doumpos et al. } \\
\text { (2017); Mahfudz (2006); Rosyadi (2007); Arsil (2007); } \\
\text { Prawira (2007); Siswantoro (2014); Abusharbeh (2016); } \\
\text { Sukmana \& Febriyati (2016); Setyawati et al. (2017); } \\
\text { Hamid et al. (2017); Saiful \& Ayu (2019) }\end{array}$ & $\begin{array}{l}\text { Not entirely appropriate to apply to } \\
\text { Islamic banks. The positivist utilitarian } \\
\text { paradigm as the main target or only } \\
\text { focuses on commercial or business } \\
\text { performance (Hameed et al., 2004). }\end{array}$ \\
\hline $\begin{array}{l}\text { Islamicity Index and } \\
\text { Social Performance Index }\end{array}$ & $\begin{array}{l}\text { Samad \& Hasan (2000); Hameed et al., (2004); } \\
\text { Setiawan (2009); Aisjah \& Hadianto (2013); Mukhibad } \\
\text { et al., (2017); Wiranata \& Rama (2018); Sabirin (2018); } \\
\text { Mutia et al. (2019) }\end{array}$ & $\begin{array}{l}\text { It is still partial and has not accommodated } \\
\text { all Islamic banks' objectives, and the } \\
\text { method is not developed further. Only a } \\
\text { complementary performance measure of } \\
\text { financial performance. }\end{array}$ \\
\hline $\begin{array}{l}\text { Three objective } \\
\text { Maqashid Index }\end{array}$ & $\begin{array}{l}\text { Mohammed et. al. (2008); Mohammed \& Taib (2009 } \\
\text { \& 2015); Qasim, et al. (2017) }\end{array}$ & $\begin{array}{l}\text { Made in a partial dimension, causing } \\
\text { the indicators obtained can not be used } \\
\text { to evaluate the Maqashid performance } \\
\text { of Islamic banks holistically (Ascarya } \\
\text { et al., 2017). From the beginning, it } \\
\text { was developed by negating financial } \\
\text { (commercial) measures and being a } \\
\text { complementary performance measure. }\end{array}$ \\
\hline $\begin{array}{l}\text { Eight objective Maqashid } \\
\text { Index }\end{array}$ & Asutay \& Harningtyas (2015) & $\begin{array}{l}\text { Too complicated and impractical to use, so } \\
\text { no one uses it in the subsequent research. }\end{array}$ \\
\hline $\begin{array}{l}\text { Islamic Bank Maqashid } \\
\text { Index }\end{array}$ & Ascarya et al. (2017) & $\begin{array}{l}\text { Cannot be used at this time because the } \\
\text { data needed by } 65 \text { elements and their } \\
\text { proxies require a new information and } \\
\text { reporting system that must be designed } \\
\text { by the authority (OJK) to accommodate } \\
\text { new data (new ratios and proxies) }\end{array}$ \\
\hline
\end{tabular}


Next, Ascarya et al. (2017) outlined the dimensions of elements and elements to ratios from sub-aspects using the Sekaran's Method by involving practitioners, experts, and regulators. This process expects to produce elements and ratios that are relevant, measurable, and the data can be obtained and not limited by only available data and reports. With the Sekaran's Method, the dimensions, elements, and ratios (or proxies) of the 65 elements generated. A proxy derives from an element by finding the ratio that best reflects that element, regardless of whether the data is available or not.

The application or use of the Islamic Bank Maqashid Index following the results of Ascarya et al. (2017) research can take several alternatives. First, Islamic Bank Maqashid Index directly adopted the overall model with 65 elements from 5 (five) Commercial sub-aspects, 4 (four) Social sub-aspects, and 4 (four) Macro sub-aspects. Second, Islamic Bank Maqashid Index adopted an initial model with 30 elements, ten elements each for Commercial, Social and Macro aspects. Third, Islamic Bank Maqashid Index adopts a core model with one of the essential sub-aspect elements for the three Commercial, Social and Macro aspects (details see Table 3).

Ascarya et al. (2017) research on Islamic Bank Maqashid Index continued and aimed to produce a holistic index, which tends to be complicated and impractical. This model cannot use as well because, as stated, it requires the development of a new Islamic bank reporting system for authorities, especially the Financial Services Authority (OJK) and Bank Indonesia (BI). The proxies they used chosen were not limited to existing reports but with specific special needs that are not present in Islamic banking reporting. In general, it can identify that the research of Ascarya et al. (2017) is the latest research seeking to develop alternative methods for measuring Islamic banks' performance.

\section{Conclusion}

Eventually, the measurement of Islamic bank performance mostly uses performance measurements similar to conventional bank performance measurements using financial ratios and efficiency (technical and cost). This performance measurement model tends to pay attention to shareholders' financial goals only and does not pay attention to broader stakeholder goals, as well as economic goals and other social goals. With these conditions, there is a strong aspiration to develop alternative models for measuring Islamic banks' performance to reflect their nature and objectives better. However, the development of Islamic bank performance measurement models is still limited and in the initial stages from the beginning of Islamic banks' development up to the present time. Some examples are the Islamicity Index, Economic Contribution and Muslim Communities, Social Performance Index, Maqashid Index, and Islamic Bank Maqashid Index. These models from the results of this study still have several weaknesses. The Islamicity Index, Economic Contributions, and the Muslim Community, and the Social Performance Index are still straightforward and have not been developed by researchers. Some subsequent studies use the Islamicity Index and Social Performance Index to assess Islamic banks' performance without further developing the methods and elements. 
Furthermore, it also concludes that there are many studies on the performance of Islamic banks that use the Maqashid Index, and there have been several attempts to build their methods with various variants. Nevertheless, some weaknesses of the Maqashid Index that have existed, among others, are made in a partial dimension. This condition causes the indicators obtained can not be used to evaluate the performance of Islamic banks holistically. The development of the Maqashid Index with a more complex dimension also caused the model's inability to be used by subsequent researchers because of its complexity and the availability of data standards that still require changes in the information system of the authority.

Therefore, it is still necessary to develop methods for measuring the performance of Islamic banks that are relevant to their nature and purpose in the future. A relevant, useful, and comprehensive performance measurement is vital for the effectiveness, resilience, and sustainability of Islamic banks' development in the future. Moreover, the performance measurement method also needs to absorb executive officials and decision-makers' aspirations in the management of Islamic banks and regulators. This condition is essential so that the performance measurement methods formulated close to the possibility of their use in Islamic bank strategic management practices are not merely academic studies.

\section{References}

Abbas, M., Azid, T. \& Besar, M. H. A. H. (2016). Efficiency, Effectiveness and Performance Profile of Islamic and Conventional Banks in Pakistan. Humanomics, 32(1), 2-18. https://doi.org/10.1108/H-09-2015-0058.

Abid, I., Goaied, M. \& Ammar, M. B. (2018). Conventional and Islamic Banks' Performance in the Gulf Cooperation Council Countries; Efficiency and Determinants. Journal of Quantitative Economics, 17(2). 1-43. https://doi.org/10.1007/s40953-018-0139-2.

Abusharbeh, M. T. (2016). Analysis the Effect of Islamic Banks Performance on Depositor's Fund: Evidence from Indonesia. International Journal of Economics and Finance, 8(10), 40-47. https://doi.org/10.5539/ijef.v8n10p40.

Ahmad, S. \& Rahim, A. R. A. (2012). The Efficiency of Islamic and Conventional Commercial Banks in Malaysia. International Journal of Islamic and Middle Eastern Finance and Management, 5(3), 241-263. https://doi.org/10.1108/17538391211255223.

Aisjah, S. \& Hadianto, A. E. (2013). Performance Based Islamic Performance Index (Study on the Bank Muamalat Indonesia and Bank Syariah Mandiri). Asia-Pacific Management and Business Application, 2(2), 98-110. https://doi.org/10.21776/ ub.apmba.2013.002.02.2.

Airout, R. M. \& Airout, R. M. (2017). Evaluation of Financial Performance of Islamic Banks in Jordan (2001-2010): A Comparative Study. International Journal of Economics and Finance, 9(9), 166-174. https://doi.org/10.5539/ijef.v9n9p166.

Alkheil, A. M. A., Burghof, H. P. \& Khan, W. A. (2013). Comparative Performance of Islamic and Conventional Banks in Europe. American Journal of Finance and Accounting, 3(1), 1-23. https://doi.org/10.1504/AJFA.2013.057167. 
Alon, I., Anderson, J., Munim, Z. H. \& Ho, A. (2018). A Review of The Internationalization of Chinese Enterprises. Asia Pacific Journal of Management, 35(3), 573-605. https:// doi.org/10.1007/s10490-018-9597-5.

Antonio, M. S., Sanrego, Y. D., \& Taufiq, M. (2012). An Analysis of Islamic Banking Performance: Maqasid Index Implementation in Indonesia and Jordania. Journal of Islamic Finance, 1(1), 12-29.

Arsil, F. (2007). Analisis Kinerja Bank Syariah Ditinjau dari Pengaruh Eksternal (Studi Kasus: Bank Syariah Mandiri Periode Januari 2001 - Juni 2003) (Analysis of Islamic Bank Performance in terms of External Influence (Case Study: Bank Syariah Mandiri). Jurnal EKSIS-PSTTI UI, 3(1), 35-49.

Ascarya, Sukmana, R. \& Rahmawati, S. (2016). Formulating Islamic Bank Maqasid Index. In: A. G. Ismail, S. S. Ali \& L. B. M. Hameed (eds). Policy Discussion Papers on Maqasid Shariah for Socio-economic Development, 1-34. Selangor: KUIS.

Ascarya, Hakim, C. M., \& Rahmawati, S. (2017). Merancang Indeks Maqashid Bank Syariah (Formulating Islamic Bank Maqashid Index). BI Working Paper. Bank Indonesia.

Asutay, M. (2007). Conceptualisation of The Second Best Solution in Overcoming The Social Failure of Islamic Finance: Examining the Overpowering of Homoislamicus by Homoeconomicus. IIUM Journal in Economics and Management, 15(2), 167-195.

Asutay, M. (2012). Conceptualising and Locating the Social Failure of Islamic Finance: Aspirations of Islamic Moral Economy vs. The Realities of Islamic Finance. Asian and African Area Studies, 11(2), 93-113. https://doi.org/10.14956/asafas.11.93

Asutay, M \& Harningtyas, A. F. (2015). Developing Maqasid al-Shari'ah Index to Evaluate Social Performance of Islamic Banks: A Conceptual and Empirical Attempt. International Journal of Islamic Economics and Finance Studies, 1(1), 5-64.

Bank of Indonesia [BI]. (2007). PBI No. 9 Tahun 2007 tentang Sistem Penilaian Tingkat Kesehatan Bank Umum Berdasarkan Prinsip Syariah (Bank Indonesia Regulation concerning the Rating System for the Soundness of Islamic Banks). Jakarta: Bank of Indonesia.

Suresh, C. \& Bardastani, M. (2016). Financial Performance of Selected Conventional and Islamic Banks in Kingdom of Bahrain - A CAMEL Ranking Based Approach. European Journal of Contemporary Economics and Management, 3(1), 23-59.

Bedoui, H. E., \& Mansour, W. (2015). Performance and Maqasid Al-shari'ah's PentagonShaped Ethical Measurement. Science and Engineering Ethics, 21(3), 555-576. https:// doi.org/10.1007/s11948-014-9561-9.

Carton, R. B. (2004). Measuring Organizational Performance: An Exploratory Study. (Unpublished Dissertation). Faculty of The University of Georgia, Athens, Georgia.

Carton, R. B. \& Hofer, C. W. (2006). Measuring Organizational Performance: Metrics for Entrepreneurship and Strategic Management Research. Cheltenham: Edward Elgar.

Dewi, A. C., Fitriana, A., \& Setiawan, D. (2018). Perkembangan Penelitian di Bidang 
Pengungkapan di Indonesia: Telaah Konseptual (Research developments in the Field of Disclosure in Indonesia: Conceptual Study). Jurnal Siasat Bisnis, 22(1), 1-19. https:// doi.org/10.20885/jsb.vol22.iss1.art1.

Doumpos, M., Hasan, I., \& Pasiouras, F. (2017). Bank Overall Financial Strength: Islamic versus Conventional Banks. Economic Modelling, 64(1), 513-523. https://doi. org/10.1016/j.econmod.2017.03.026.

El-Mosaid, F. \& Boutti, R. (2012). Relationship between Corporate Social Responsibility and Financial Performance in Islamic Banking. Research Journal of Finance and Accounting, 3(10), 93-103.

Eljelly, A. M. A. \& Elobeed, A. A. (2013). Performance Indicators of Banks in a Total Islamic Banking System: The Case of Sudan. International Journal of Islamic and Middle Eastern Finance and Management, 6(2), 142-155. https://doi. org/10.1108/17538391311329833.

Erol, C., Baklaci, H. F., Aydogan, B. \& Tunc D. (2014). Performance Comparison of Islamic (Participation) Banks and Commercial Banks in Turkish Banking Sector. EuroMed Journal of Business, 9(2), 114 - 128. https://doi.org/10.1108/EMJB-05-2013-0024.

Fetscherin, M., \& Heinrich, D. (2015). Consumer Brand Relationships Research: A Bibliometric Citation Meta-analysis. Journal of Business Research, 68(2), 380-390. https://doi.org/10.1016/j.jbusres.2014.06.010.

Hadriche, M. (2015). Banks Performance Determinants: Comparative Analysis between Conventional and Islamic Banks from GCC Countries. International Journal of Economics and Finance, 7(9), 169-177. http://dx.doi.org/10.5539/ijef.v7n9p169.

Hafez, M. M. H. (2018). Examining the Relationship between Efficiency and Capital Adequacy Ratio: Islamic versus Conventional Banks - An Empirical Evidence on Egyptian Banks. Accounting and Finance Research, 7(2), 232-247. https://doi. org/10.5430/afr.v7n2p232.

Hamidi, M. L., \& Worthington, A. C. (2018). Islamic Social Banking: The Way Forward. Jurnal Ekonomi Malaysia, 52(1), 179-190.

Hameed, S., Pramano, S., Alrazi, B., \& Bahrom, N. (2004). Alternative Disclosure and Performance for Islamic Bank's. Proceeding of The Second Conference on Administrative Science: Meeting The Challenges of The Globalization Age. Dahran, Saud Arabia.

Hamid, A., Majid, M. S. A., \& Khairunnisah, L. (2017). An Empirical Re-examination of The Islamic Banking Performance in Indonesia. International Journal of Academic Research in Economics and Management Sciences, 6(2), 219-232. https:// doi.org/10.6007/ IJAREMS/v6-i2/3022.

Hartono, S. \& Sobari, A. (2017). Sharia Maqashid Index as A Measuring Performance of Islamic Banking: A More Holistic Approach. Corporate Ownership \& Control, 14(2), 193-200.

Hasan, M. M., \& Dridi, J. (2010). The Effects of the Global Crisis on Islamic and Conventional Banks: A Comparative Study. IMF Working Papers, No. 10/201, 1-46. 
Hasan, M. M., \& Dridi, J. (2011). The Effects of the Global Crisis on Islamic and Conventional Banks: A Comparative Study. Journal of International Commerce, Economics and Policy, 2(2), 163-200. https://doi.org/10.1142/S1793993311000270.

Hosen, M. N., Jie, F., Muhari, S. \& Khairman, M. (2019). The Effect of Financial Ratios, Maqasid Sharia Index, and Index of Islamic Social Reporting to Profitability of Islamic Bank in Indonesia. Al-Iqtishad: Jurnal Ilmu Ekonomi Syariah (Journal of Islamic Economics), 11(2), 201-222. https://doi.org/10.15408/aiq.v11i2.11588.

Hussein, M. E., Alam, Md. M., \& Murad, Md. W. (2019). The Performance of Islamic Banks during the 2008 Global Financial Crisis: Evidence from the Gulf Cooperation Council Countries. Journal of Islamic Accounting and Business Research, 10(4), 1-14. https://doi.org/10.1108/JIABR-01-2017-0011.

Ifeacho, C., \& Ngalawa, H. (2014). Performance of The South African Banking Sector Since 1994. Journal of Applied Business Research, 30(4), 1183-1196. https://doi.org/10.19030/ jabr.v30i4.8663.

Johnes, J., Izzeldin, M. \& Pappas, V. (2014). A Comparison of Performance of Islamic and Conventional Banks 2004-2009. Journal of Economic Behavior \& Organization, 103(1), 93-107. https://doi.org/10.1016/j.jebo.2013.07.016.

Johnes, J., Izzeldin, M. Pappas, V. \& Alexakis, C. (2018). Performance and Productivity in Islamic and Conventional Banks: Evidence from the Global Financial Crisis. Economic Modelling, 65(1), 1-33. https://doi.org/10.1016/j.econmod.2018.09.030.

Kamarudin, F., Hue, C. Z., Sufian, F. \& Mohamad Anwar, N. A. (2017). Does Productivity of Islamic Banks Endure Progress or Regress? Empirical Evidence Using Data Envelopment Analysis Based Malmquist Productivity Index. Humanomics, 33(1), 84118. https://doi.org/10.1108/H-08-2016-0059.

Kasim, S., \& Majid, M. (2010). Impact of Financial Shocks on Islamic Banks: Malaysian Evidence During 1997 to 2007 Financial Crisis. International Journal of Islamic and Middle Eastern Finance and Management, 3(4), 291-305. https://doi. org/10.1108/17538391011093243.

Khan, I., Khan, M. \& Tahir, M. (2017). Performance Comparison of Islamic and Conventional Banks: Empirical Evidence from Pakistan. International Journal of Islamic and Middle Eastern Finance and Management, 10(3), 419-433. https://doi. org/10.1108/IMEFM-05-2016-0077.

Khediri, K. B., Charfeddine, L., \& Youssef, S. B. (2015). Islamic versus Conventional Banks in The GCC Countries: A Comparative Study Using Classification Techniques. Research in International Business and Finance, 33(1), 75-98. https://doi.org/10.1016/j. ribaf.2014.07.002.

Kouser, R., \& Saba, I. (2012). Gauging The Financial Performance of Banking Sector Using CAMEL Model: Comparison of Conventional, Mixed and Pure Islamic Banks in Pakistan. International Research Journal of Finance and Economics, 82, 67-88.

Laela, S. F. (2014). Dynamic Strategic-fit dan Kinerja: Studi pada Perbankan Syariah (Dynamic 
Strategic-fit and Performance: Study on Islamic Banking). Jurnal Akuntansi dan Keuangan Indonesia, 11(1), 20-39. https:// doi.org/10.21002/jaki.2014.02.

Logofatu, M. \& Stefanescu, C. (2017). Theoretical Perspective Concerning Organizational Performance Measurement. Economic Sciences, 16(1), 113-119.

Lucianetti, L., Battista, V. \& Koufteros, X. (2019). Comprehensive Performance Measurement Systems Design and Organizational Effectiveness. International Journal of Operations \& Production Management, 39(2), 326-356. https://doi.org/10.1108/ IJOPM-07-2017-0412.

Mahfudz, A. A. (2006). Performance Evaluation of Islamic Commercial Banks In Indonesia After The Financial Crisis. Tazkia Islamic Finance \& Business Review, 1(2), 93-107.

Masum, A. K. M., Azad, M. A. K. \& Beh, L. S. (2016). The Role of Human Resource Management Practices in Bank Performance. Total Quality Management \& Business Excellence, 27(3-4), 382-397. https://doi.org/10.1080/14783363.2014.1002762.

Mobarek, A. \& Kalonov, A. (2014). Comparative Performance Analysis Between Conventional and Islamic Banks: Empirical Evidence from OIC countries. Applied Economics, 46(3), 253-270. https://doi.org/10.1080/00036846.2013.839863.

Mohammed, Dzuljastri \& Taib. (2008). The Performance Measures of Islamic Banking Based on the Maqashid Framework. Paper of IIUM International Accounting Conference (INTAC IV).

Mohammed, M. O., \& Taib, F. M. (2009). Testing The Performance Meaasured Based on Maqashid al-Shariah (PMMS) Model on 24 Selected Islamic and Conventional Banks. In Proceding of the Insaniah-IRTI International Conference of Islamic Economics, Banking, and Finance.

Mohammed, M. O., \& Taib, F. M. (2015). Developing Islamic Banking Performance Measures Based on Maqasid al-Shariah Framework: Cases of 24 Selected Banks. Journal of Islamic Monetary Economics and Finance (JIMF), 1(1), 55-77. https://doi. org/10.21098/jimf.v1i1.483.

Mohd Nor, S. (2016). Islamic Social Bank: An Adaptation of Islamic Banking. Jurnal Pengurusan, 46(1), 43-52.

Mohd Nor, S., Rahim, R. A., \& Senik, Z. C. (2016). The Potential of Internalizing Social Banking Among the Malaysian Islamic Banks. Environment, Development and Sustainability, 18(2), 347--372. https://doi.org/10.1007/s10668-015-9651-0.

Mukhibad, H., Kiswanto, N.A. \& Jayanto, P. Y. (2017). An Analysis on Financial and Social Performance of Islamic Banks in Indonesia. International Journal of Monetary Economics and Finance, 10(3), 295-309. https://doi.org/10.1504/IJMEF.2017.087479.

Mutia, A., Jannah, R. \& Rahmawaty, R. (2019). Islamicity Performance Index of Islamic Banking in Indonesia. Proceedings of the 1st Aceh Global Conference (AGC). https://doi. org/10.2991/agc-18.2019.65.

Neely, A., Edgeman, R. \& Huber, G. (2015). Performance Measurement Effects on Organizational Responses to Threats. Measuring Business Excellence, 19(1), 24-32. https://doi.org/10.1108/MBE-11-2014-0048. 
Noman, A. H. M., Pervin, S., Chowdhury, N. J., Hossain, Md. A. \& Banna, H. (2015). Comparative Performance Analysis between Conventional and Islamic Banks in Bangladesh-An Application of Binary Logistic Regression. Asian Social Science, 11(21), 248-257. https://doi.org/10.5539/ass.v11n21p248.

Prawira, H. (2007). Perbandingan Kinerja PT. Bank Jabar Syariah Sebelum dan Sesudah Fatwa MUI Tentang Haramnya Bunga Bank (Performance Comparison of PT. Bank Jabar Syariah Before and After the MUI Fatwa Regarding the Unlawful Bank Interest). Jurnal EKSIS-PSTTI UI, 3(1), 51-65.

Qasim, Y. R., Mohamad, Y., \& Ibrahim, N. (2017). Measuring the Performance of Jordanian Islamic Banks. Journal of Public Administration and Governance, 7(1), 25-47. https:// doi.org/10.5296/jpag.v7i1.10575 .

Rahim, A., Rahman, A. R. A., \& Rosman, R. (2013). Efficiency of Islamic Banks: A Comparative Analysis of MENA and Asian Countries. Journal of Economic Cooperation \& Development, 34(1), 63-92.

Rashid, A. \& Jabeen, S. (2016). Analyzing Performance Determinants: Conventional versus Islamic Banks in Pakistan. Borsa Istanbul Review, 16(2), 92-107. https://doi. org/10.1016/j.bir.2016.03.002.

Rosyadi, I. F. (2007). Analisis Perbandingan Kinerja Bank Syariah dengan Bank Konvensional Berdasarkan Rasio Keuangan. Studi Kasus: BMI dan 7 (tujuh) Bank Umum Konvensional (Comparative Analysis of the Performance of Islamic Banks with Conventional Banks Based on Financial Ratios). Jurnal EKSIS-PSTTI UI, 3(1), 19-33.

Rusydiana, A., \& Sanrego, Y. (2018). Measuring The Performance of Islamic Banking in Indonesia: An Aplication of Maslahah-Efficiency Quadrant (MEQ). Journal of Islamic Monetary Economics and Finance, 3 (Special Issue), 79-98. https://doi.org/10.21098/ jimf.v3i0.909.

Sabirin, (2018). Analisa Kinerja Perbankan Syariah di Indonesia dengan Islamicity Performance Index dan Islamic Corporate Governance (Performance Analysis of Islamic Banking in Indonesia with the Islamicity Performance Index and Islamic Corporate Governance). Al-Maslahah, 14(2), 237-258.

Saeed, M. \& Izzeldin, M. (2016). Examining The Relationship Between Default Risk and Efficiency in Islamic and Conventional Banks. Journal of Economic Behavior \& Organization, 132, 127-154. https://doi.org/10.1016/j.jebo.2014.02.014.

Safiullah, M. \& Shamsuddin, A. (2018). Risk in Islamic Banking and Corporate Governance. Pacific Basin Finance Journal. 47, 129-149. https://doi.org/10.1016/j. pacfin.2017.12.008.

Saiful \& Ayu, D. P. (2019). Risks Management and Bank Performance: The Empirical Evidences from Indonesian Conventional and Islamic Banks. International Journal of Economics and Financial Issues, 9(4), 90-94. https://doi.org/10.32479/ijefi.8078.

Sairally, S. (2007). Community Development Financial Institutions: Lessons in Social Banking for the Islamic Financial Industry. Kyoto Bulletin of Islamic Area Studies, 1(2), 19-37. 
Samad, A. \& Hasan, M. K. (2000). The Performance of Malaysian Islamic Bank During 1984-1997: An Exploratory Studi. International Journal of Islamic Financial Services, 1(3), 1-14. https://doi.org/10.2139/ssrn.3263331.

Schwab, D. E. (1980). Construct Validity in Organizational Behavior. In B. M. Staw, \& E. E. Cummings (Eds.), Research in Organizational Behavior, 2, 2-43. Greenwich, CT: JAI Press.

Setiawan, A. B. (2009). Analisis Kesehatan Finansial dan Kinerja Sosial Bank Syariah di Indonesia (Analysis of Financial Performance and Social Performance of Islamic Banks in Indonesia). (Unpublished Thesis). Jakarta: Paramadina University.

Setyaningsih, R., \& Setiawan, D. (2019). Recent Development of Islamic Corporate Social Responsibility. Etikonomi: Jurnal Ekonomi, 18(2), 287-302.

Setyawati, I., Suroso, S., Suryanto, T., \& Nurjannah, D. S. (2017). Does financial Performance of Islamic Banking is Better? Panel Data Estimation. European Research Studies Journal, 20(2A), 592-606.

Severgnini, E., Vieira, V. A., Galdamez, C. \& Vladimir, E. (2018). The Indirect Effects of Performance Measurement System and Organizational Ambidexterity on Performance. Business Process Management Journal, 24(5), 1176-1199. https://doi.org/10.1108/ BPMJ-06-2017-0159.

Sillah, B. M. S. \& Harrathi, N. (2015). Bank Efficiency Analysis: Islamic Banks versus Conventional Banks in the Gulf Cooperation Council Countries 2006-2012. International Journal of Financial Research, 6(4), 143-150.

Siswantoro, D. (2014). Analysis of Islamic Bank's Performance and Strategy After Spin-off as Islamic Full-Fledged Scheme in Indonesia. International Conference on Accounting Studies, 18-19 August 2014, Kuala Lumpur Malaysia.

Stefanescu, C. \& Logofatu, M. (2018). Development and Testing of a Multidimensional Model for Measuring Organizational Performance. Management \& Marketing, 16(1), 74-81.

Sukmana, R., \& Febriyati, N. A. (2016). Islamic Banks vs Conventional Banks in Indonesia: An Analysis on Financial Performances. Jurnal Pengurusan, 47(1), 81-90.

Usman, A. \& Khan, M. K. (2012). Evaluating the Financial Performance of Islamic and Conventional Banks of Pakistan: A Comparative Analysis. International Journal of Business and Social Science, 3(7), 253-257.

Venkatraman, N., \& Grant, J. (1986). Construct Measurement in Organizational Strategy Research: A Critique and Proposal. Academy of Management Review, 11(1), 71-87.

Wasiuzzaman, S. \& Gunasegavan, U. N. (2013). Comparative Study of The Performance of Islamic and Conventional Banks. Humanomics, 29(1), 43-60. https://doi. org/10.1108/08288661311299312.

Wiranata, S. \& Rama, A. (2018). Intellectual Capital dan Kinerja Sosial Perbankan Syariah di Indonesia: Sebuah Kajian Konsep dan Empiris (Intellectual Capital and Social Performance of Islamic Banking in Indonesia: A Concept and Empirical Study). Jurnal Ekonomi dan Bisnis Islam, 3(2): 195-207. 
Zaheer, R., \& Jamil, H. (2016). Performance Comparison Analysis of Islamic and Conventional Banks - Case Study of Pakistan. Journal of Philosophy, Culture and Religion, 16(1), 14-25.

Zainal, V. R. \& Putra, B. Y. (2016). Indonesia Islamic Banking Readiness in Facing the ASEAN Economic Community 2015, in terms of Islamic Banking Disclosure and Performance Indices. Online Journal of Research in Islamic Studies, 3(1), 29-42. 